\author{
Tadeusz Terlikowski ${ }^{\mathrm{a})^{*}}$ \\ a) The Main School of Fire Service / Szkoła Główna Służby Pożarniczej \\ *Corresponding author / Autor korespondencyjny: t_terlik@poczta.onet.pl
}

\title{
Civil Security Engineering or Civil Protection Engineering?
}

\section{Inżynieria bezpieczeństwa cywilnego czy inżynieria ochrony ludności?}

\begin{abstract}
Objective: This paper attempts to prove that an effective model of protecting civilians from consequences of hazards ensuing from natural events considered as natural disasters, as well as risks arising from civilisational development in the reality of a global world, is the civil security engineering system based on achievements of many scientific disciplines related to the humanities, social sciences and technical sciences. This objective is justified by the thesis that stipulates that civil security engineering is an interdisciplinary measure of numerous entities in a modern state, the task of which is ensuring security for the society as regards the protection of life and health, property and the environment as fundamental conditions for the existence of the nation. Introduction: The contemporary reality, in which the $27^{\text {st }}$ century society is functioning, creates diverse hazards for human life and health, property and the environment. Hence it is the obligation of the state to seek new effective methods that would allow combatting the consequences of such hazards. Many of those methods and tools are comprised by security engineering with civil protection engineering distinguished as a specialist discipline, which comprises means, methods and ways of organising effective protection of the society, human life and health as well as civilisational and cultural achievements of the society.

Methodology: The basic method adopted in preparing this article was a review of source materials related to hazards to the society resulting from natural phenomena and industrial environment, followed by preparing conclusions and a presentation of the complete reasoning in relation to the subject of the present article.

Conclusions: Civil protection is one of the most crucial challenges for the state security system in the context of all-encompassing globalisation, which is conducive to the generation of new hazards, especially those that result from the development of modern technologies. But also in the sphere of natural hazards we are faced with new events, i.a., due to climate change, such as extreme weather conditions, changes to annual precipitation, melting of icebergs, rise of the water level in seas and oceans, or the recent spread of epidemic hazards, which may be caused by diverse viruses, such as the current coronavirus outbreak. To be effective, the civil protection system has to be organised in a way that ensures it is capable of coping with all challenges; it needs to be able to use knowledge from many scientific fields and domains, and furthermore it also has to be an interdisciplinary system characterised not only by social knowledge, but in the first place technical know-how, and that is why we can speak of civil protection engineering.

Key words: civil protection, natural and technical hazards, rules for civil protection, safety engineering, civil security engineering, civil protection engineering Type of article: review article
\end{abstract}

Received: 05.02.2020; Reviewed: 19.02.2020; Accepted: 09.03.2020;

Author's ORCID ID: T. Terlikowski - 0000-0001-6197-4421;

Please cite as: SFT Vol. 55 Issue 1, 2020, pp. 48-61, https://doi.org/10.12845/sft.55.1.2020.4;

This is an open access article under the CC BY-SA 4.0 license (https://creativecommons.org/licenses/by-sa/4.0/).

\section{ABSTRAKT}

Cel: Celem artykułu jest próba dowiedzenia, że efektywnym modelem ochrony ludności przed skutkami zarówno zagrożeń wynikających ze zdarzeń naturalnych, jak i z rozwoju cywilizacji jest system inżynierii ochrony ludności oparty na osiągnięciach dyscyplin naukowych z dziedziny nauk humanistycznych, społecznych oraz nauk technicznych. Cel ten uzasadnia teza mówiąca, że inżynieria ochrony ludności jest interdyscyplinarnym działaniem wielu podmiotów współczesnego państwa, którego zadaniem jest zapewnienie bezpieczeństwa społeczeństwu w zakresie podstawowych warunków istnienia narodu: ochrony życia i zdrowia, mienia i środowiska.

Wprowadzenie: Współczesna rzeczywistość, w której funkcjonuje społeczeństwo XXI wieku, stwarza wiele zagrożeń dla życia i zdrowia ludzi, mienia oraz środowiska. Stąd obowiązkiem państwa jest szukanie nowych efektywnych metod pozwalających na przeciwstawienie się skutkom tych zagrożeń. Wiele metod i narzędzi dedykowanych temu celowi znaleźć można w obszarze inżynierii bezpieczeństwa - z wyodrębnieniem inżynierii ochrony ludności jako specjalistycznej dyscypliny zawierającej środki, metody i sposoby organizowania skutecznej ochrony społeczeństwa, życia i zdrowia ludzi oraz dorobku cywilizacyjnego i kulturowego społeczeństwa. 
Metodologia: Podstawową metodą zastosowaną w trakcie przygotowania artykułu była analiza materiałów źródłowych z zakresu zagrożeń dla społeczeństwa płynących ze zjawisk naturalnych i środowiska industrialnego, opracowanie wniosków i przedstawienie całości wywodów w odniesieniu do tematu artykułu.

Wnioski: Wobec powszechnej globalizacji, która sprzyja powstawaniu nowych zagrożeń, zwłaszcza tych będących wynikiem rozwoju nowoczesnych technologii, ochrona ludności stanowi dla systemu bezpieczeństwa państwa jedno z najważniejszych wyzwań. Także w obszarze zagrożeń naturalnych mamy do czynienia z nowymi zdarzeniami będącymi skutkiem np. zmian klimatycznych (ekstremalne zjawisko pogodowe, zmiany w ilości rocznych opadów atmosferycznych, topnienie lodowców, podnoszenie się poziomu wód w morzach i oceanach, szerzenie się zagrożeń epidemicznych, których przyczyną mogą być różnego rodzaju wirusy). Aby system ochrony ludności był efektywny, powinien czerpać wiedzę z różnych obszarów i dziedzin nauki oraz dyscyplin naukowych, wykazywać się interdyscyplinarnością, wykorzystywać nie tylko wiedzę społeczną, prawną, ale przede wszystkim techniczną. Stąd możemy mówić o inżynierii ochrony ludności.

Słowa kluczowe: ochrona ludności, zagrożenia naturalne i techniczne, zasady ochrony ludności, inżynieria bezpieczeństwa, inżynieria bezpieczeństwa cywilnego, inżynieria ochrony ludności

Typ artykułu: artykuł przeglądowy

Przyjęty: 05.02.2020; Zrecenzowany: 19.02.2020; Zaakceptowany: 09.03.2020;

Identyfikator ORCID: T. Terlikowski - 0000-0001-6197-4421:

Proszę cytować: SFT Vol. 55 Issue 1, 2020, pp. 48-61, https://doi.org/10.12845/sft.55.1.2020.4;

This is an open access article under the CC BY-SA 4.0 license (https://creativecommons.org/licenses/by-sa/4.0/).

\section{Introduction}

Before an attempt is made at answering the title of the article, it is necessary to present the story of the concept of "safety", along with its evolution over the years, and especially the recent period - characterised by geopolitical changes and the dynamic development of civilisation related to technological development and its influence on the human environment.

We are currently facing a number of phenomena of an unprecedented scale and magnitude, resulting both from human activities and powerful natural forces. The contemporary society has a particular need to have a sense of security, value and safe future, because, after all, security has always constituted a significant need in the life of people [1, p. 62]. For years now the need for security in the form of rules and bans defining the admissible solutions and the ensuing required behaviour of people has been an inherent element of how interpersonal relations are regulated. Such requirements for human behaviour in the form of religious laws may be found among others in the Deuteronomy, which contains the following statement: "When thou buildest a new house, then thou shalt make a battlement for thy roof, that thou bring not blood upon thine house, if any man fall from thence" [2, p. 9]. From the viewpoint of security, this is certainly one of the requirements that allow safe usage of the house. This is because the identification and utilisation of an appropriate security system, as well as the determination of appropriate systemic and legal solutions, results from the development of interpersonal and international relations, and in the first place from rapid economic growth.

As a result of social and political transformations, security ceased to be perceived as a military domain and the military sphere. The term of security has been expanded both vertically by furthering the concept of safety to comprise new subjects and objects that need to have security ensured, as well as horizontally, by extending the concept of security to comprise new areas or entities it is related to. Such an evolution of the concept was particularly pronounced in the 1970s. Objects, or subjects, of safety are now human groups, communities, as well as countries, regions or entire international systems. On the other hand,

\section{Wstęp}

Przed próbą odniesienia się do pytania zawartego w tytule artykułu należy przedstawić historię pojęcia "bezpieczeństwo" i jego ewolucji na przestrzeni lat. W szczególności ostatnie były bowiem naznaczone zmianami geopolitycznymi i gwałtownym rozwojem cywilizacji idącym w parze z postępem technologii, które znacząco wpłynęły na środowisko człowieka.

Aktualnie występujące zjawiska, charakterystyczne ze względu na swoją skalę i rozmiary, wynikają zarówno z działań samego człowieka, jak i potężnych sił przyrody. Współczesne społeczeństwo odczuwa szczególną potrzebę poczucia bezpieczeństwa, wartości i pewności jutra - wszakże bezpieczeństwo od zawsze stanowiło istotną potrzebę w życiu człowieka [1, s. 62]. Potrzeba ta, w formie nakazów i zakazów określających dopuszczalne rozwiązania i związane z tym konieczne zachowanie się ludzi, jest od lat nieodłącznym elementem regulacji stosunków międzyludzkich. Takie wymagania zachowań ludzkich $w$ formie nakazów religijnych można odczytać na przykład już w Księdze Powtórzonego Prawa, gdzie znajduje się następujący zapis: „Jeśli zbudujesz dom, uczynisz na dachu ogrodzenia, byś nie obciążał swego domu krwią, gdyby ktoś z niego spadł" [2, s. 9]. Z punktu widzenia bezpieczeństwa na pewno jest to jeden $z$ warunków umożliwiających bezpieczne użytkowanie domu. Określenie i stosowanie odpowiedniego systemu bezpieczeństwa, a także wskazywanie właściwych rozwiązań systemowych i prawnych wynika bowiem z rozwoju stosunków międzyludzkich i międzynarodowych, a przede wszystkim z gwałtownego rozwoju gospodarczego.

Zmiany społeczno-polityczne spowodowały, że bezpieczeństwo przestało być postrzegane jako domena militarna, sfera wojskowości. Nastąpiło rozbudowanie pojęcia, zarówno wertykalnie - poprzez jego rozszerzenie o nowe podmioty, obiekty, którym bezpieczeństwo należy zapewnić, jak i horyzontalnie - poprzez zwiększenie zasięgu pojęcia bezpieczeństwo o nowe obszary czy też przedmioty, których bezpieczeństwo dotyczy. Taka ewolucja pojęcia daje się zauważyć od lat 70-tych ubiegłego stulecia. Obiektami bezpieczeństwa, jego podmiotami stali się: człowiek, grupy ludzkie, społeczności, a także państwa, regiony czy całe systemy 
security fields now comprise political, military, economic, power engineering, ecological, cultural systems, including also ideological and social ones, etc. As may be seen from its definition and colloquial understanding, security has been understood for years (and perhaps even centuries) as a state that guarantees to countries and communities the certainty of their existence, survival and certainty which ensures further development.

As emphasised by P. Majer [3, p. 11] the approach to security understood as mere guarantee of the existence of the state and its survival is nowadays considered a conservative approach. Security involves not only guaranteeing the existence of the state, its inviolability and development, but also ensuring the appropriate functioning of a particular area of state operation, a guarantee of the safety of its citizens under the man-technology-environment system [2, p. 10]. Economic growth and the consequent economic transformations required ensuring the required security level, including also the devising of relevant systems of legal, organisational and functional solutions, as well as regulations pertaining to interpersonal relations [2, p. 9]. The most pronounced changes in the approach to understanding of security and its application have taken place as a result of a dynamic development of technologies, and in particular cutting-edge technical solutions, which have not been used before, such as for example space industry, introduction of artificial intelligence, peaceful use of nuclear energy by developing nuclear energy etc. Such a situation required on the one hand the adoption of solutions related to societal organisation (among others extending societal education to include topics related to security, such as for example occupational safety and health, defence training, including self-defence and defence education), and, on the other hand, ensuring the safety of machinery, equipment of technological lines, buildings and structures, to make sure that they do not become a source of threat for people and property.

Extending the concept of security onto other entities, objects, and areas resulted in the necessity of having this concept particularised, which consequently led to the establishing of various proposals for its classification. All those attempts at finding a definition or structuring clearly indicate that there is a great interest in these topics. This in turn resulted in the formal recognition of security as a scientific discipline' ${ }^{1}$. This recognition results from the fact that security is the "most important value, a nationwide need and a priority objective of the operation of the state, social entities and groups, and concurrently a process that comprises diverse means guaranteeing a life free of interferences and possibilities of development, including state security and protection of individuals and of the entire society, its goods and the natural environment from hazards that endanger goods covered by special protection" [4, p. 117]. Based on such an all-embracing definition of security, its division may be made for example with view to subjectiveness (national security, international security) or assuming objectiveness as a basis for division,

\footnotetext{
For the first time security was recognised as a scientific field under the name of "security sciences" in 2011, see: Regulation of the Minister of Science and Higher Education on areas of knowledge, fields of science and art as well as scientific and artistic disciplines of 8 August 2011 (Polish Journal of Laws/Dz.U. No. 179, item 1065); the currently binding Regulation of the Minister of Science and Higher Education on branches of science and scientific disciplines and artistic disciplines of 20 September 2018 (Polish Journal of Laws/Dz.U. 2018 item 1818) assigns security sciences to the field of social sciences as a scientific discipline.
}

międzynarodowe. Do obszarów bezpieczeństwa zaczęły zaliczać się: systemy polityczne, militarne, ekonomiczne, energetyczne, ekologiczne, kulturowe (w tym ideologiczne, społeczne itp.). Bezpieczeństwo, jak wynika z definicji pojęcia i jego potocznego znaczenia, przez wiele lat (może nawet stuleci) rozumiane było jako stan gwarantujący państwom, społeczeństwom pewność ich istnienia, przetrwania, która dawała również gwarancję rozwoju.

Współcześnie, jak podkreśla P. Majer [3, s. 11], postrzeganie bezpieczeństwa wyłącznie jako gwarancji istnienia państwa i jego przetrwania jest nazywane konserwatywnym. Obecnie bezpieczeństwo oznacza nie tylko zapewnienie istnienia państwa, jego nienaruszalności, gwarancji istnienia i rozwoju, ale również zapewnienie funkcjonowania poszczególnych dziedzin państwa, gwarancji bezpieczeństwa jego obywateli w układzie człowiek-technika-środowisko [2, s. 10]. Rozwój gospodarczy oraz związane z nim zmiany spoteczne wymagały zapewnienia odpowiedniego poziomu bezpieczeństwa, w tym opracowania właściwych rozwiązań prawnych, organizacyjnych, funkcjonalnych oraz uregulowań z zakresu stosunków międzyludzkich [2, s. 9]. Największe zmiany w podejściu do rozumienia bezpieczeństwa i jego stosowania nastąpiły w wyniku gwałtownego rozwoju technologii, zwłaszcza nowoczesnych rozwiązań technicznych, które nigdy wcześniej nie były stosowane (np. przemysł kosmiczny, wprowadzenie sztucznej inteligencji, pokojowe wykorzystanie energii atomowej poprzez budowę energetyki jądrowej itp.). Sytuacja taka wymagała z jednej strony zastosowania rozwiązań z obszaru organizacji społeczeństwa (m.in. wprowadzenie do edukacji społeczeństwa zagadnień takich jak bezpieczeństwo i higiena pracy, szkolenie obronne - w tym powszechna samoobrona, edukacja obronna), a z drugiej strony zapewnienia bezpieczeństwa maszyn, urządzeń linii technologicznych, budynków i obiektów, aby nie stanowiły one źródła zagrożeń dla osób i mienia.

Rozszerzenia pojęcia bezpieczeństwo na inne podmioty, obiekty, obszary prowadziło do konieczności uszczegółowienia tego terminu, co w konsekwencji zaowocowało wieloma propozycjami jego systematyk. Wszystkie próby definiowania, systematyzowania dobitnie świadczą o dużym zainteresowaniu poruszaną problematyką. To z kolei przełożyło się na formalne uznanie bezpieczeństwa za dyscyplinę naukową'. Jego powodem było stwierdzenie, że jest to "najważniejsza wartość, potrzeba narodowa i priorytetowy cel działalności państwa, jednostek i grup społecznych, a jednocześnie proces obejmujący różnorodne środki gwarantujące trwały, wolny od zakłóceń byt i rozwój w tym obronę państwa oraz ochronę jednostek i całego społeczeństwa, ich dóbr i środowiska naturalnego przed zagrożeniami, które godzą w dobra podlegające szczególnej ochronie" [4, s. 117]. Z tak obszernej definicji bezpieczeństwa można dokonać jego podziału np. ze względu na podmiotowość (bezpieczeństwo narodowe, bezpieczeństwo międzynarodowe) albo - biorąc za podstawę podziału przedmiotowość - można wyróżnić bezpieczeństwo polityczne, militarne, ekonomiczne, społeczne,

\footnotetext{
Po raz pierwszy bezpieczeństwo uznano za dyscyplinę naukową pod nazwą „nauki o bezpieczeństwie" w 2011 roku, patrz: Rozporządzenie Ministra Nauki i Szkolnictwa Wyższego z 8 sierpnia 2011 r. w sprawie obszarów wiedzy, dziedzin nauki i sztuki oraz dyscyplin naukowych i artystycznych (Dz.U. Nr 179, poz.1065); aktualnie obowiązujące rozporządzenie Ministra Nauki i Szkolnictwa Wyższego z 20 września 2018 r. w sprawie dziedzin nauki i dyscyplin naukowych oraz dyscyplin artystycznych (Dz.U. 2018 poz. 1818) sytuuje nauki o bezpieczeństwie w dziedzinie nauk społecznych jako dyscyplinę naukową.
} 
we may mention political, military, economic, social, religious, ideological, maritime, aviation, ecological, climate-related, internal, external, technical, civil, health-related, foodstuff, sanitary, legal and societal security etc. [3]. Coming up with a closed catalogue of security appears to be impossible and, given its objectiveness, new hazards may appear that would require specific security principles to be created. Once issues related to security have been introduced to the field of science and practice, a domain was created (in the colloquial understanding of the word) of knowledge, science as well as studies defined as "safety engineering". It was recognised as a field of study in 2007 when the minister of science and higher education defined the standards of education for the field of study (major) of safety engineering [5]. The presented characteristics and definitions, and, first of all, formal and legal regulations suggest that appropriate rank has been given to these issues in science and in processes that affect the security conditions of the modern civilisation.

\section{Safety engineering - definition, conceptual and functional scope}

Safety engineering has been established and is based on principles worked out under reliability theory.

Given the dramatic development of civilisation, and consequently also technologies available at the time, recognition was given to the necessity of studying relations between the development of sciences and technology, on the one hand, and environmental conditions that reduce society's adjustment potential to constantly changing living conditions arising from rapidly shifting civilisational requirements [2, p.10]. S. Radkowski wrote that this necessity led to the creation of technological development forecasts taking into account broadly understood consequences in the man- technology-environment system in the context of their impact on humans and on the environment. Those studies comprised estimates of the types, scope and magnitude of such impact in relation to individual types of technology. In addition, those estimates also contained assessments of the positive and negative effects. These studies were based on the thesis that each human activity entails a specific risk understood as a product of the likelihood of an event and potential losses resulting from it. Studies suggesting a solution to the problem of assessing and analysing the level of security take into account societal expectations and limitations that arise from the adopted solutions [2, p.11].

Consequently, the security level is a criterial function that limits the state of technology, and its identification is one of the tasks of safety engineering, and namely the identification of possibilities of reducing technical risk already at the construction stage of building structures. In this respect particular importance is gained by the necessity of carrying out analyses related to reducing the state of uncertainty as to the projected time until failure and correct scenario for the course of the event, as well as total costs necessary to eliminate its consequences. In the opinion of S. Radkowski [2, p. 15-16] the performance of such an analysis requires the adoption of suitable methods and tools appropriate for engineering processes, and this is where the concept of safety engineering is derived from. kulturowe, religijne, ideologiczne, morskie, lotnicze, ekologiczne, klimatyczne, wewnętrzne, zewnętrzne, techniczne, cywilne, zdrowotne, żywnościowe, sanitarne, prawne, powszechne, itp. [3]. Wydaje się, że nie sposób opisać zamkniętego katalogu bezpieczeństwa, uwzględniając jego przedmiotowość. Zawsze mogą pojawić się nowe zagrożenia, których skutki będą podstawą do określania zasad bezpieczeństwa. Wraz z wprowadzeniem problematyki bezpieczeństwa do obszaru nauki i praktyki powstała dziedzina (w potocznym znaczeniu tego słowa) wiedzy, nauki, a także studiów, określona jako „inżynieria bezpieczeństwa”. Została uznana jako kierunek studiów w 2007 r., kiedy minister nauki i szkolnictwa wyższego określił standardy kształcenia na kierunku studiów inżynieria bezpieczeństwa [5]. Z przedstawionych charakterystyk oraz pojęć definicyjnych, a przede wszystkim regulacji formalno-prawnych wynika, że niniejszej problematyce została nadana odpowiednia ranga w nauce i procesach kształtujących warunki bezpieczeństwa we współczesnej cywilizacji.

\section{Inżynieria bezpieczeństwa - definicja, zakres pojęciowo-funkcjonalny}

Inżynieria bezpieczeństwa powstała i opiera się na zasadach wypracowanych przez teorię niezawodności.

Wraz z bardzo gwałtownym rozwojem cywilizacji i technologii dostrzeżono konieczność badania związków pomiędzy rozwojem nauki i techniki a środowiskowymi warunkami ograniczającymi możliwości adaptacyjne społeczeństwa do stale zmieniających się warunków życia, które wynikają z bardzo dynamicznie zmieniających się wymogów cywilizacyjnych [2, s.10]. W efekcie powstały, jak pisze S. Radkowski, opracowania prognozy rozwoju techniki uwzględniające szeroko rozumiane skutki w systemie człowiek-technika-środowisko pod kątem ich oddziaływania na człowieka i środowisko. Opracowania te zawierały szacunki rodzajów, zakresu i wielkości tych oddziaływań w odniesieniu do danych rodzajów technologii, a także oceny skutków pozytywnych i negatywnych. Podstawą opracowań była teza, że z każdą działalnością człowieka wiąże się określone ryzyko, rozumiane jako iloczyn prawdopodobieństwa zaistnienia zdarzenia i jego potencjalnych strat. Opracowania zawierające rozwiązanie problemu oceny $\mathrm{i}$ analizy poziomu bezpieczeństwa uwzględniają społeczne oczekiwania i ograniczenia wynikające z zastosowanych rozwiązań $[2$, s.11].

Poziom bezpieczeństwa jest więc kryterialną funkcją ograniczającą stan techniki, a jego określenie jest jednym z zadań inżynierii bezpieczeństwa (a dokładnie możliwości zmniejszenia poziomu ryzyka technicznego już na etapie konstruowania obiektów). Szczególnego znaczenia nabiera konieczność przeprowadzenia analizy zmniejszenia stanu niepewności odnoszącej się do prognozy czasu do awarii i prawidłowego scenariusza przebiegu zdarzenia, a także sumarycznych kosztów usuwania jego skutków. S. Radkowski [2, s. 15-16] wyjaśnia, że przeprowadzenie takiej analizy wymaga zastosowania odpowiednich metod i narzędzi właściwych dla procesów inżynieryjnych - stąd właśnie pochodzi określenie inżynieria bezpieczeństwa.

Ogólnymi zadaniami inżynierii bezpieczeństwa bez względu na jej przedmiot są miedzy innymi [2, s. 16]: 
The general tasks of safety engineering, regardless of its subjects are as follows [2, p.16]:

- identification of essential security standards,

- determination of studies aimed at meeting security criteria,

- specification of hazard identification methods for the purposes of security,

- setting up rules for the organisation and functioning of security,

- specification of general requirements and needs specific to local conditions, and in addition formal and legal regulations in the scope of responsibility for security and for impact on the environment.

An exceptionally important element of safety engineering is the development and adoption of procedures to be followed to allow, i.a., the following:

- identification of potential hazards at each stage of functioning of the security area,

- risk assessment of identified hazards,

- determination of the risk acceptability level,

- determination of ways, methods and tools, as well as resources (including financial ones) needed to minimise the risk, for example by adoption of additional security means.

The implementation of the abovementioned measures should allow the devising of appropriate procedures oriented at undertaking appropriate measures and methods as a result of conducted risk analysis and assessment, including in the first place those that are considered as prerequisites for the achievement and ensuring of the required security level.

Procedures for the selection of security criteria in each domain require engineering knowledge from individual areas of technique, technology, management etc. This is due to the fact that as stated fittingly by M. Lutostański [6, p. 175], an obvious thesis may be posed that in addition to good theory provided by security sciences, the security of any object or subject also needs sound techniques. And sound techniques may be ensured by the development of technical sciences with an autonomic scientific discipline, which should be safety engineering. And as further stated by M. Lutostański [6, p. 176] security sciences may not be perceived exclusively in the context of military issues. Consequently, there is a need for a safety engineering science, which should comprise a wide spectrum of phenomena that make the surrounding reality more suitable to expectations of enhancing the safety culture, first of all with respect to technical development.

Therefore, it may be assumed that safety engineering is a specific interdisciplinary scientific discipline that incorporates in the sphere of safety assurance tools and conceptual apparatus of such disciplines, as for example environmental engineering, material engineering, power engineering, mechanics, transport, construction and many other similar technical scientific disciplines. Security science - specified in the list of scientific fields and disciplines - does not include technical or engineering problems, which are indispensable in the planning, organisation and establishing of security systems on various organisational levels, in state, self-government, economic or non-government organisations. As regards non-military security, safety engineering is necessary for the purposes of identification and
- określenie istotnych norm bezpieczeństwa,

- określenie badań mających na celu spełnienie wymagań bezpieczeństwa,

- określenie metod identyfikacji zagrożeń dla bezpieczeństwa,

- sformułowanie zasad organizacji i funkcjonowania bezpieczeństwa,

- określenie wymagań ogólnych oraz wymagań dotyczących warunków lokalnych, miejscowych, a ponadto regulacji formalnoprawnych z zakresu odpowiedzialności za bezpieczeństwo, oddziaływań na środowisko.

Niezwykle istotnym elementem inżynierii bezpieczeństwa jest opracowanie i wprowadzenie procedur postępowania umożliwiających między innymi:

- identyfikację zagrożeń możliwych do wystąpienia na każdym etapie funkcjonowania przedmiotu bezpieczeństwa,

- oszacowanie ryzyka w odniesieniu do zidentyfikowanych zagrożeń,

- ustalenie poziomu akceptowalności ryzyka,

- określenie sposobów, metod i narzędzi oraz środków (w tym finansowych) niezbędnych do minimalizacji ryzyka poprzez np. zastosowanie dodatkowych środków bezpieczeństwa.

W wyniku realizacji powyższych przedsięwzięć powinny zostać opracowane odpowiednie procedury umożliwiające podjęcie stosownych środków i metod, prowadzących do osiągnięcia i zapewnienia wymaganego poziomu bezpieczeństwa.

Procedury wyboru kryteriów bezpieczeństwa w każdej dziedzinie wymagają wiedzy inżynierskiej z poszczególnych obszarów techniki, technologii, zarządzania itp. Bowiem, jak słusznie pisze M. Lutostański [6, s. 175], można postawić oczywistą tezę, że bezpieczeństwo dowolnego podmiotu lub przedmiotu - oprócz dobrej teorii, którą mają zapewnić nauki o bezpieczeństwie - potrzebuje również dobrej techniki. Tę może zaoferować w szczególności rozwój nauk technicznych z autonomiczną dyscypliną naukową, jaką powinna być inżynieria bezpieczeństwa. Jak konstatuje przywołany autor [6, s. 176], nauki o bezpieczeństwie nie mogą być postrzegane wyłącznie w kontekście problemów militarnych. Chodzi tu więc o naukę inżynierii bezpieczeństwa, która powinna obejmować szerokie spektrum zjawisk czyniących otaczającą rzeczywistość bardziej odpowiadającą oczekiwaniom podnoszącym kulturę bezpieczeństwa, przede wszystkim w zakresie technicznego rozwoju.

Można zatem przyjąć, że inżynieria bezpieczeństwa stanowi swoistego rodzaju interdyscyplinarną dyscyplinę naukową integrującą w sferze zapewnienia bezpieczeństwa narzędzia i aparaturę pojęciową z inżynierii środowiska, inżynierii materiałowej, energetyki, mechaniki, transportu, budownictwa i wielu innych technicznych dyscyplin naukowych. Nauka o bezpieczeństwie - zawarta w wykazie dziedzin i dyscyplin naukowych - nie uwzględnia problematyki technicznej, inżynierskiej, która jest niezbędna w planowaniu, organizowaniu i tworzeniu systemów bezpieczeństwa na różnych poziomach organizacyjnych - zarówno w instytucjach państwowych, samorządowych, gospodarczych, jak i organizacjach pozarządowych. Odnosząc się do bezpieczeństwa pozamilitarnego, inżynieria bezpieczeństwa jest niezbędna do rozpoznawania i szacowania ilościowego oraz jakościowego 
qualitative and quantitative assessment of hazards, methods, ways and means of combatting such hazards, reconstruction of lands, facilities and other elements of environmental infrastructure, and restoration of the environment afflicted by the consequences of hazards. It may be reasonably assumed that the basis in those measures consists primarily of tools used in technical sciences, in engineering practice. In practical terms, the functional scope of safety engineering integrates security issues distributed among diverse scientific disciplines.

It may be assumed that safety engineering is a well-structured scientific area, related to studies of the essence of natural hazards, hazards arising from civilisational development and man-made hazards, resulting from human activity, including also the development of modern technologies that determine the development of contemporary civilisation. This is a hazard area resulting from the man-technology-environment relationship, also bearing the name of the Technology Assessment theory (TA), coined in the USA, under which studies were carried out aimed at assessing the type, scope and magnitude of impact exerted by a given technology on the society and environment in the long- and medium-term, allowing for positive and negative effects [2, p. 11]. This shows that environmental engineering comprises hazards originating from that system, both potential and dynamic ones, which appear suddenly, in most cases randomly, in emergency states and in situations with an adverse impact on human life and health, causing losses to property and degradation of the natural environment, with particular emphasis on the natural environment. Research tools in safety engineering comprise a full spectrum of engineering tools commonly used in the first place in technical sciences, but also in the field of social sciences in economics, law, management etc.

In practical terms, safety engineering has developed as a scientific discipline despite the fact that it is not formally indicated as an independent scientific discipline.

The fields of practice where safety engineering is functioning are the ever developing in this respect research and development activities, teaching activities ${ }^{2}$, practical and planning activities, for example in the development of zoning plans and plans of response to hazards and elimination of their consequences, as well as reconstruction of entities afflicted by consequences of those hazards.

For years safety engineering has made use of a conceptual framework specific for the theory of security developed during long-term activity, which is reflected in diverse separate specialties - safety engineering in the work environment, fire safety engineering, civil security engineering ${ }^{3}$ and other ones, with an objective definition, such as for example technical security engineering etc. It also involves studying the impact of emergency situations in industry on the surroundings. Such studies cover the analysis of

\footnotetext{
According to the materials serving as a basis for the development of an application for recognising safety engineering as an independent scientific discipline, which are at the author's disposal, in 2014 in Polish university schools there were 18 "security engineering" majors, and they were also present in 9 schools in Europe, USA and Canada. Moreover, 8 Polish scientific and research institutes and 7 domestic organisations and associations and 15 foreign organisations and associations, recognised safety engineering as a topic subject to studies and analyses. Issues of security engineering are additionally a subject of popularisation in 28 Polish journals and 26 foreign journals. Furthermore, security engineering is also the subject of numerous domestic and international scientific conferences.

3 In the Main School of Fire Service under the general field of study of "safety engineering" two principal specialties are being implemented: fire safety engineering and civil security engineering.
}

zagrożeń, metod, sposobów i środków zwalczania tych zagrożeń, odbudowy terenów, obiektów i innych przedmiotów infrastruktury środowiska, odtwarzania środowiska dotkniętego skutkami zagrożeń. Za podstawę działań śmiało można uznać wyłącznie narzędzia stosowane w naukach technicznych, w praktyce inżynierskiej. Inżynieria bezpieczeństwa scala w swoim obszarze funkcjonalnym problematykę bezpieczeństwa rozproszoną w różnych dyscyplinach naukowych.

Można stwierdzić, że stanowi ona dobrze usystematyzowany obszar naukowy, powiązany z badaniem istoty zagrożeń naturalnych, zagrożeń wynikających z rozwoju cywilizacyjnego i zagrożeń spowodowanych przez człowieka, wynikających z jego działalności - w tym rozwoju nowoczesnych technologii -stanowiących o rozwoju współczesnej cywilizacji. Jest to obszar zagrożeń wynikających z powiązania zależności człowiek-technika-środowisko, nazywany też teorią Technology Assesment (TA). Prowadzone $w$ jej ramach badania miały na celu szacowanie typu, zakresu i wielkości oddziaływania określonej technologii na społeczeństwo i środowisko w ujęciu długo- i średnioterminowym, z uwzględnieniem skutków pozytywnych i negatywnych [2, s. 11]. Inżynieria środowiska obejmuje więc zagrożenia wynikające z tego systemu (zarówno potencjalne, jak i dynamiczne), pojawiające się nagle, najczęściej losowo, w stanach awaryjnych i negatywnie oddziałujących na życie i zdrowie ludzi, powodujących straty w mieniu i degradację środowiska naturalnego, ze szczególnym zwróceniem uwagi na środowisko przyrodnicze. Narzędziami badawczymi w inżynierii bezpieczeństwa jest pełne spektrum narzędzi inżynierskich stosowanych powszechnie, przede wszystkim w naukach technicznych, ale także w obszarze nauk społecznych: ekonomii, prawie, zarządzaniu.

W praktyce inżynieria bezpieczeństwa ukształtowała się jako dyscyplina naukowa, pomimo iż nie jest formalnie wskazana jako taka.

W obszarze inżynierii bezpieczeństwa coraz bardziej rozwija się działalność naukowo-badawcza, dydaktyczna², praktyczno-planistyczna (np. tworzenie planów zagospodarowania przestrzennego, reagowania na zagrożenia, likwidacji ich skutków, a także odbudowa podmiotów dotkniętych skutkami tych zagrożeń).

Inżynieria bezpieczeństwa od lat posługuje się wypracowanym w wyniku wieloletniej działalności, specyficznym dla teorii bezpieczeństwa aparatem pojęciowym. Znajduje on swoje odzwierciedlenie w różnych wyodrębnionych specjalnościach - inżynierii bezpieczeństwa w środowisku pracy, inżynierii bezpieczeństwa pożarowego, inżynierii bezpieczeństwa cywilnego ${ }^{3} \mathrm{i}$ innych określonych przedmiotowo (np. inżynierii bezpieczeństwa technicznego). Inżynieria bezpieczeństwa zajmuje się ponadto badaniem wpływu na otoczenie skutków awarii przemysłowych. Badania

\footnotetext{
Według materiałów służących do opracowania wniosku o uznanie inżynierii bezpieczeństwa jako samodzielnej dyscypliny naukowej, będących w posiadaniu autora, w 2014 r. w uczelniach polskich funkcjonowało 18 kierunków studiów „inżynieria bezpieczeństwa" i w 9 uczelniach europejskich, USA i Kanady. Ponadto w 8 krajowych instytutach naukowo-badawczych oraz $\mathrm{w} 7$ organizacjach i stowarzyszeniach krajowych i 15 organizacjach i stowarzyszeniach zagranicznych, inżynieria bezpieczeństwa była przedmiotem badań i analiz. Ponadto problematyka inżynierii bezpieczeństwa jest przedmiotem popularyzacji w 28 czasopismach krajowych i 26 czasopismach zagranicznych. Inżynieria bezpieczeństwa jest ponadto przedmiotem wielu krajowych i międzynarodowych konferencji naukowych.

W Szkole Głównej Służby Pożarniczej w ramach ogólnego kierunku studiów „inżynieria bezpieczeństwa" realizowane są dwie specjalności: inżynieria bezpieczeństwa pożarowego i inżynieria bezpieczeństwa cywilnego.
} 
methods and means aimed at minimising consequences that may be caused by such failures. Their scope involves not only safety analyses of the equipment, but also the facilities, technological processes, transport, storage e.g. of hazardous materials. Consequently, it may be assumed that, in the context of scientific procedures, safety engineering defines the relationships between potential and actual natural disasters and technical failures with the surroundings, in which such failures or disasters may occur or which have already occurred. Taking a holistic look at problems of hazards in the system man-technology-environment, it becomes possible to define in an unequivocal way the sphere of interest of safety engineering, for which it is impossible to deny social and economic usefulness of its study results related to protection from consequences of contemporary hazards and the civilisational challenges of the contemporary world.

Taking into consideration the presented characteristics of safety engineering, the following definition may be proposed: "safety engineering is an activity connected with the design, construction, usage and decommissioning of technical facilities, which comprise all the generated products, assembly systems, machines, plant, technical installations including their fittings, interrelated in a structural and functional scope, with the aim of minimising possibilities and magnitude of their negative impact on people, their property and the environment, as well as all civilisational achievements, including also planning, designing, organisation and functioning of security systems and modern technologies aimed at the prevention and elimination of consequences of adverse impact of technical facilities and natural phenomena on the surroundings to ensure protection of the life and health of humans and goods of the contemporary society".

\section{Civil security engineering}

This extensive concept of safety engineering has been split into several types in relation to the subject - technical security engineering, safety in the working environment, fire safety engineering, civil security engineering, engineering of systems safety, transport security engineering (air, railway, land and maritime transport) and many others. As the subject of the present article is an analysis of civil security engineering, in the further part of the deliberations the author will only discuss this issue in the context of civil protection.

Civil security engineering was described by W. Pihowicz $[7$, p. 5], who states that safety engineering that formed a new scientific discipline contains topics related to the following: technical security engineering, civil security engineering.

According to him, the co-dependence of tasks and methods of their implementation within technical security engineering and civil security engineering is oriented at achieving the combined goal of safety engineering, which is the rational maximisation of civil protection, the natural environment and civilisational goods. And this particular purpose may be implemented only by ensuring an appropriate combination of successful tasks in both fields (areas) constituting safety engineering. More about this co-dependence may be found in Inżynieria bezpieczeństwa technicznego. Problematyka podstawowa [7, p. 18, fig. 2.1]. takie obejmują analizę metod i sposobów ograniczania skutków awarii. Bardzo często wykraczają poza analizę bezpieczeństwa maszyn i urządzeń i obejmują także obiekty, całe procesy technologiczne, warunki transportu i magazynowania, zwłaszcza materiatów niebezpiecznych dla zdrowia i życia ludzi ze względu na swoje własności. Można zatem powiedzieć, że inżynieria bezpieczeństwa na drodze naukowej określa związki potencjalnych i realnych katastrof naturalnych oraz awarii technicznych z otoczeniem, w którym takie awarie bądź katastrofy mogą wystąpić albo już wystąpiły. Patrząc holistycznie na problematykę zagrożeń w systemie człowiek-technika-środowisko, można w sposób jednoznaczny określić obszar zainteresowań inżynierii bezpieczeństwa. Rezultaty jej badań niosą w sobie użyteczność społeczną i gospodarczą w ochronie przed skutkami współczesnych zagrożeń i wyzwań cywilizacyjnych współczesnego świata.

Biorąc pod uwagę przedstawioną charakterystykę inżynierii bezpieczeństwa, można zaproponować jej definicję: „inżynieria bezpieczeństwa, to działalność związana z projektowaniem, budową, eksploatacją i likwidacją obiektów technicznych, którymi są wszystkie wytworzone wyroby, zespoły systemów, maszyn, urządzeń, instalacji technicznych wraz z ich osprzętem, związanych ze sobą w sensie strukturalnym, jak i funkcjonalnym w celu zminimalizowania możliwości i rozmiaru ich negatywnego oddziaływania na ludzi, ich mienie i środowisko i wszystkie osiągnięcia cywilizacyjne, a także planowanie, projektowanie, organizowanie i funkcjonowanie systemów bezpieczeństwa oraz nowoczesnych technologii zapobiegania i usuwania skutków negatywnego oddziaływania obiektów technicznych i zjawisk naturalnych na otoczenie w celu ochrony życia i zdrowia ludzi oraz dóbr współczesnego społeczeństwa".

\section{Inżynieria bezpieczeństwa cywilnego}

Z tak szerokiego pojęcia inżynierii bezpieczeństwa powstało wiele jej rodzajów odnoszących się do przedmiotu - inżynieria bezpieczeństwa technicznego, inżynieria bezpieczeństwa w środowisku pracy, inżynieria bezpieczeństwa pożarowego, inżynieria bezpieczeństwa cywilnego, inżynieria bezpieczeństwa systemów, inżynieria bezpieczeństwa transportu (lotniczego, kolejowego, lądowego, morskiego) i innych. Ponieważ przedmiotem artykułu jest analiza inżynierii bezpieczeństwa cywilnego, $w$ dalszej części rozważań autor ograniczy się wyłącznie do tego wątku w kontekście ochrony ludności.

W. Pihowicz [7, s. 5] twierdzi, że inżynieria bezpieczeństwa, jako nowa dyscyplina naukowa, zawiera $w$ swoim pojęciu zagadnienia dotyczące zarówno inżynierii bezpieczeństwa technicznego, jak i inżynierii bezpieczeństwa cywilnego. Według niego współzależność zadań i sposobów ich realizacji w ramach działania obydwu ukierunkowana jest na racjonalną maksymalizację ochrony ludzi, środowiska naturalnego i dóbr cywilizacji - co stanowi cel całej inżynierii bezpieczeństwa. Może być on urzeczywistniony tylko poprzez właściwą kombinację pozytywnych realizacji zadań w obydwu dziedzinach (obszarach), z których składa się inżynieria bezpieczeństwa. Więcej o tej współzależności można znaleźć w publikacji pt. Inżynieria bezpieczeństwa technicznego. Problematyka podstawowa [7, s. 18, ryc. 2.1]. 
Special position and role of civil security engineering is acquired by counteracting and mastering adverse effects arising directly from natural disasters (floods, hurricanes, earthquakes, landslides, torrential precipitation, extreme temperatures, epidemics etc.), as well as technical disasters (i.a. events due to destructive human actions consisting of sabotage or terrorist acts). The types of such events to which civil security engineering is applicable are illustrated by Figure 1 .
Szczególne miejsce i rola inżynierii bezpieczeństwa cywilnego przypadają przeciwdziałaniu i opanowaniu negatywnych skutków wywołanych bezpośrednio przez katastrofy naturalne (powodzie, huragany, trzęsienia ziemi, osuwiska, gwałtowne opady atmosferyczne, występowanie ekstremalnych temperatur, epidemie itp.), a także katastrofy techniczne (w tym zdarzenia powstałe w wyniku destrukcyjnych działań człowieka w postaci aktów sabotażu czy aktów terrorystycznych). Rodzaje takich zdarzeń, w stosunku do których ma zastosowanie inżynieria bezpieczeństwa cywilnego, ilustruje rycina 1.

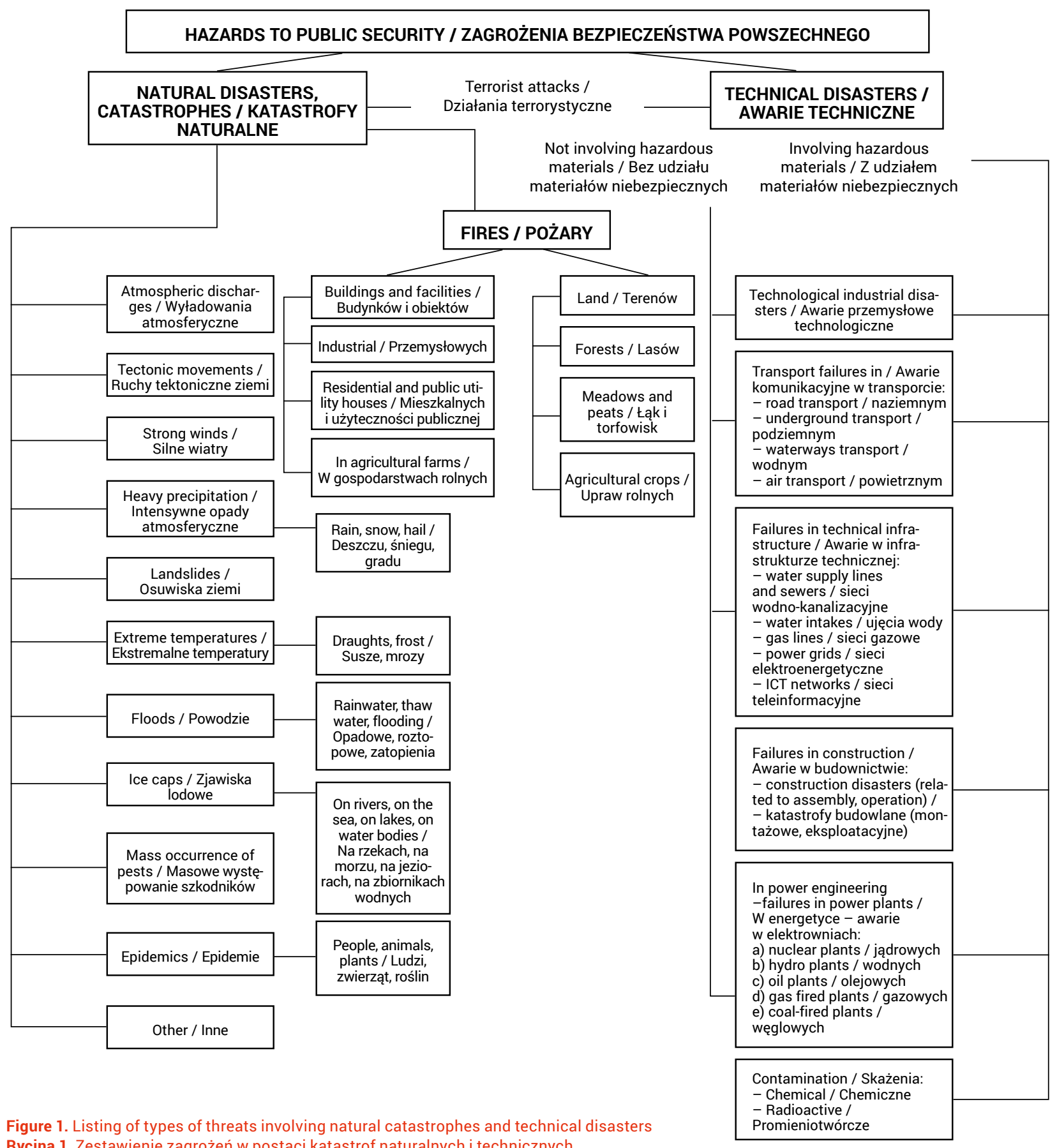

Rycina 1. Zestawienie zagrożeń w postaci katastrof naturalnych i technicznych 
Natural catastrophes and technical disasters lead to adverse consequences, which comprise tangible and intangible damage. The concept of damage comprises among others human death and injuries - non-measurable damage, damage or harm to the natural environment - measurable and non-measurable damage, destruction or damage to civilisational goods - measurable goods [7, p. 135], [2, p. 19]. The basic, direct and most frequent causes of damage involve the destructive action of diverse forces, phenomena or substances, as for example mechanical forces, thermal radiation, ionising radiation, electric current and chemical toxic substances. Destructive impacts causing damage, albeit to a lesser extent, may arise from magnetic fields, electric fields, acoustic fields etc. More about the extent of the damage is written by S. Radkowski [2, s. 19, fig. 3.1].

It may be assumed that for safety engineering, including civil security engineering, the estimation of losses that could be incurred due to a hazard, for example to natural or technical disasters, is one of the basic elements in developing security plans aimed at ensuring protection from consequences of such events.

When defining the possibility of the occurrence of a loss and assessing its potential magnitude, an analysis should be carried out comprising, i.a.:

- the so-called mechanism underlying the damage, including: likelihood of the event and the possibility of occurrence of a consequence of an undesired event [7, p. 242],

- identification of tangible and intangible losses as an immediate result of the event,

- costs that have to be borne in order to prepare the appropriate response to the event (appropriate amount and types of human and financial resources and means), and that had to be allocated for compensation of losses during the so-called restoration to the condition prior to the event.

For more about the damage occurrence mechanism see W. Pihowicz [7, p. 242, fig. 9.5].

The activity described above is one of a number of elements in the entire process of civil security engineering, which is frequently called management of catastrophic risk. It is the object of attention of numerous entities of government administration, regional and local government administration, economic entities, non-government organisations, institutions, inspections, foundations, charities and humanitarian organisations ${ }^{4}$.

When describing civil security engineering and its development one should keep in mind the role played in the process by the Main School of Fire Service. The stimulus to begin education in civil security engineering were the changes in how fire protection was functioning in Poland [8]. In implementing the educational programme for fire engineer officers, in line with the Act on fire protection and also taking into consideration local events other than a fire that pose a hazard to the human life or health, property and the environment, which require taking up appropriate interventions by numerous different entities, a decision was

\footnotetext{
Tasks for diverse entities functioning within the state in respect to crisis management have been defined in several legal regulations with the rank of an act, as for example: Acts on regional government, on district local government, on commune local government, on crisis management, on the state of a natural disaster; the Act on central public administration bodies and many others.
}

Katastrofy naturalne i techniczne wywołują szkody materialne i niematerialne. Pod pojęciem szkód przyjęło się rozumieć między innymi śmierć i obrażenia u ludzi (szkody niemierzalne), zniszczenie lub uszkodzenie środowiska naturalnego (szkody mierzalne i niemierzalne), zniszczenia lub uszkodzenia tworów cywilizacji (szkody mierzalne) [7, s. 135], [2, s. 19]. Podstawową, bezpośrednią i najczęstszą przyczyną powstawania szkód jest niszczące działanie różnych sił, zjawisk czy substancji, takich jak siły mechaniczne, promieniowanie cieplne, promieniowanie jonizujące, prądy elektryczne, chemiczne substancje toksyczne. Działania niszczące - chociaż w mniejszym zakresie - mogą powodować pola magnetyczne, pola elektryczne, fale akustyczne itp. Więcej o rozległości szkód pisze S. Radkowski [2, s. 19, ryc. 3.1].

Można przyjąć, że dla inżynierii bezpieczeństwa - w tym inżynierii bezpieczeństwa cywilnego - szacowanie szkód, które mogą powstać w wyniku zmaterializowania się zagrożenia np. ze strony katastrof naturalnych czy technicznych, jest jednym z podstawowych elementów opracowywania planów bezpieczeństwa przed skutkami takich zdarzeń.

Określając możliwość powstania szkody i jej potencjalną wielkość, należy poddać analizie przede wszystkim:

- tzw. mechanizm powstania szkody, a w tym: prawdopodobieństwo powstania zdarzenia oraz możliwość zaistnienia konsekwencji niepożądanego zdarzenia [7, s. 242];

- identyfikację szkód materialnych i niematerialnych jako natychmiastowy rezultat powstałego zdarzenia;

- koszty, które należy ponieść w celu przygotowania właściwej reakcji na zaistniałe zdarzenie (odpowiednia ilość, rodzaje sił i środków ludzkich, sprzętowych, finansowych) oraz jakie należy przeznaczyć na kompensację strat przy tzw. odbudowie czyli przywrócenia stanu sprzed zdarzeniem.

Więcej o mechanizmie powstawania szkód patrz [7, s. 242, ryc. 9.5].

Opisana powyżej działalność stanowi jeden z wielu elementów $w$ całym procesie inżynierii bezpieczeństwa cywilnego i często nosi nazwę zarządzania ryzykiem katastroficznym. Jest ono przedmiotem uwagi podmiotów administracji rządowej, administracji samorządowej, podmiotów gospodarczych, organizacji pozarządowych, instytucji, inspekcji, fundacji i organizacji charytatywnych, humanitarnych ${ }^{4}$.

Opisując rozwój inżynierii bezpieczeństwa cywilnego, nie sposób pominąć roli, jaką odegrała w tym procesie Szkoła Główna Służby Pożarniczej. Impulsem do podjęcia kształcenia studentów w obszarze inżynierii bezpieczeństwa cywilnego były zmiany w charakterze funkcjonowania ochrony przeciwpożarowej $w$ kraju [8]. Kierując się postanowieniami ustawy o ochronie przeciwpożarowej uwzględniającej także inne aniżeli pożar miejscowe zdarzenie zagrażające życiu, zdrowiu ludzi, mieniu oraz środowisku, wymagające podjęcia odpowiednich interwencji przez wiele podmiotów, postanowiono rozpocząć kształcenie w tzw. zakresie

\footnotetext{
Zadania dla różnych podmiotów funkcjonujących w państwie w zakresie zarządzania kryzysowego określone są w szeregu aktów prawnych mających rangę ustawy, np.: ustawy o samorządzie wojewódzkim, powiatowym, gminnym, o zarządzaniu kryzysowym, o stanie klęski żywiołowej; ustawy o centralnych urzędach administracji publicznej i wiele innych.
} 
made to begin teaching in the so-called civil security engineering sensu stricto". As a result of such measures the school started teaching in the scope of fire safety engineering (for candidates for fire engineer officers) and in the field of civil safety engineering for candidates from various levels of administration: public, economic, etc. of organisations and institutions, which are obligated under the act to implement tasks in the field of counteracting the effects of other local hazards.

To sum up our discussion of civil security engineering, it may be presumed that it fulfils a rudimentary role in the effective reduction of adverse effects of events such as:

- natural hazards, such as extreme atmospheric phenomena (torrential rainfall, heavy snow fall, hail), extreme temperature (heat, cold), floods (rainwater, thaw water, stormwater on the sea coastal line, hurricanes, landslides, epidemics among people, animals and plants), fires, especially of forests or agricultural cultivations, etc.,

- hazards arising from human activity as a result of civilisational development, comprising technical disasters, industrial breakdowns, including potential terrorist or sabotage actions, mass demonstrations, street riots, long-lasting strikes and other events that may occur in the surroundings.

The core of civil security engineering includes:

- preventing hazards caused both by natural catastrophes and technical disasters,

- preparing entities and systems that guarantee the safety of people and the environment from consequences of natural and civilisational hazards,

- development of methods and ways of responding in situations where potential hazards turn into dynamic ones, caused by a natural catastrophe or a technical civilisational disaster, aimed at minimising the effects of their adverse impact on the surroundings (people and the environment),

- planning of actions related with public security in connection with a specific situation following a technical disaster or natural catastrophe.

The scope of actions of civil security engineering comprises developing methods, solutions and means necessary to effectively ensure safety for the protected entities (people, civilisational surroundings, natural environment) from hazards resulting from natural catastrophes or technical civilisational disasters. Measures in civil security engineering include rational minimising of losses generated by the adverse impact of events of a natural character and events that are civilisation-related.

These primarily include the following measures:

- appropriate evacuation of people and essential components of the natural environment and civilisational goods from areas of adverse impact of consequences of catastrophic events and events caused by humans, such as technical disasters,

- appropriate elimination or neutralisation of substances harmful to the surroundings, radiation or magnetic waves or power surges.

It should be assumed that civil security engineering constitutes a supplementation for other areas of security aimed at inżynierii bezpieczeństwa cywilnego sensu stricte. Uczelnia zaoferowała studia na kierunku inżynierii bezpieczeństwa pożarowego (przeznaczone dla kandydatów na inżynierów oficerów pożarnictwa) i inżynierii bezpieczeństwa cywilnego (adresowane do kandydatów z różnych podmiotów administracji publicznej, gospodarczej oraz innych organizacji i instytucji, które na mocy ustawy zobowiązane są do realizacji zadań z zakresu przeciwdziałania skutkom innych miejscowych zagrożeń).

Reasumując rozważania na temat inżynierii bezpieczeństwa cywilnego, można przyjąć, że spełnia ona podstawową rolę w skutecznym zmniejszaniu negatywnych skutków zdarzeń, m.in.:

- zagrożeń naturalnych, takich jak ekstremalne zjawiska atmosferyczne (gwałtowne opady deszczu, śniegu, gradu), ekstremalne temperatury (upały, mrozy), powodzie (opadowe, roztopowe, sztormowe na linii brzegowej morza, huragany, osuwiska ziemi, epidemie wśród ludzi, zwierząt i roślin), pożary, zwłaszcza lasów czy upraw rolnych itp.,

- zagrożeń będących następstwem działalności człowieka i rozwoju cywilizacyjnego w postaci katastrof technicznych, awarii przemysłowych, w tym możliwych działań terrorystycznych lub sabotażowych, masowych demonstracji, zamieszek ulicznych, długotrwałych strajków itp. zdarzeń w otoczeniu.

Istotą inżynierii bezpieczeństwa cywilnego jest między innymi:

- zapobieganie powstawaniu zagrożeń wywoływanych zarówno przez katastrofy naturalne, jak i katastrofy techniczne,

- zabezpieczenie podmiotów oraz systemów zapewniających bezpieczeństwo ludności i środowiska przed skutkami zagrożeń naturalnych i cywilizacyjnych,

- opracowywanie metod i sposobów reagowania w sytuacjach przekształcenia się zagrożeń potencjalnych w zagrożenia dynamiczne, powstałych w wyniku katastrofy naturalnej czy też katastrofy technicznej (cywilizacyjnej), mających na celu minimalizację skutków ich negatywnego oddziaływania na otoczenie (ludność i środowisko),

- planowania działań związanych z bezpieczeństwem ludności w związku z powstałą sytuacją po katastrofie technicznej czy też katastrofie naturalnej.

Inżynieria bezpieczeństwa cywilnego obejmuje doskonalenie metod i środków dla skutecznego zapewnienia bezpieczeństwa chronionym podmiotom (ludziom, otoczeniu cywilizacyjnemu, środowisku naturalnemu) przed zagrożeniami będącymi skutkami katastrof naturalnych i katastrof technicznych (cywilizacyjnych). Działaniami inżynierii bezpieczeństwa cywilnego jest racjonalna minimalizacja szkód generowanych negatywnym oddziaływaniem zdarzeń o podłożu naturalnym i zdarzeń o podłożu cywilizacyjnym.

Są to przede wszystkim takie zadania jak:

- odpowiednia ewakuacja ludzi oraz istotnych składników środowiska naturalnego i dóbr cywilizacji z obszarów negatywnego oddziaływania skutków zdarzeń katastroficznych i zdarzeń spowodowanych przez człowieka (katastrofy techniczne),

- odpowiednie usunięcie lub unieszkodliwienie niebezpiecznych dla otoczenia substancji, promieniowania, fal magnetycznych lub elektroenergetycznych. 
protecting human life and health, property and the environment from adverse consequences of technical catastrophes caused in the majority of cases by human activity or the impact of technical facilities on the surroundings, as well as natural disasters primarily brought about by natural causes ${ }^{5}$.

\section{Civil protection, civil protection engineering}

Civil protection as a measure in the field of the safety of human life and health as well as property has been functioning since the introduction of civil defence. Civil defence was associated with the protection of civilians during armed conflicts. The first measures in the field of civil defence aimed at protecting civilians during armed conflicts were undertaken already after the end of World War I. Taking up actions in protection of civilians from consequences of armed actions was commenced in a situation of victims of air bombing implemented for the first time in the history of wars. The first countries which established organisations that started civil protection were France, England and Germany. This organisation was referred to as the air defence system. In Poland the first decisions were taken in 1921, when the Polish Airborne and Antigas Society was founded, from the transformation of which under the act of 25 March 1934 the air and antigas defence was established.

After World War II civil defence underwent numerous transformations, and in 1967 by force of the Act dated 21 November the activities of the National Civil Defence were made official under the structure of the national defence ministry. Its responsibilities for the first time comprised tasks related to civil protection during natural calamities and catastrophes. Civil defence was been reflected in international law in relation to the protection of civilians during armed conflicts [9].

As a result of the development of international relations, expansion of international cooperation, establishment of various mechanisms such as agreements, international conventions, including widespread globalisation, hazards arising from armed conflicts of an international nature have become less significant. With the technological progress, civilisational achievements, the human impact on the climate and the environment, new hazards have been created for human health and life, property and the environment. They involve extreme climate-related events as well as technical disasters.

The concept of "civil defence" has been used for many years, referring to a wide range of actions aimed at assuring safety to people, property and the environment. The functioning canon of contemporary countries was now extended by the obligation of protecting human life and health, property and cultural heritage as well as the natural environment in situation of hazards due to natural causes or hazards arising from human activity as hazards of contemporary civilisation. Hazards of contemporary civilisation may be said to include, apart from natural hazards, also such hazards as asymmetric hazards, terrorist hazards, cybernetic hazards, hybrid hazards and other threats caused by man

\footnotetext{
Presently it may be assumed that civil security engineering is now facing an extremey difficult task of protecting people and the environment from consequences of climate disorders arising from irresponsible human activity.
}

Należy przyjąć, że inżynieria bezpieczeństwa cywilnego stanowi uzupełnienie innych obszarów bezpieczeństwa mających za zadanie ochronę życia i zdrowia ludzi, mienia i środowiska przed negatywnymi skutkami katastrof technicznych wywoływanych najczęściej poprzez działalność ludzi bądź oddziaływanie obiektów technicznych na otoczenie, jak i katastrof naturalnych powodowanych najczęściej z przyczyn przyrodniczych ${ }^{5}$.

\section{Ochrona ludności, inżynieria ochrony ludności}

Ochrona ludności jako działanie w zakresie bezpieczeństwa życia i zdrowia ludzi oraz mienia funkcjonuje od czasów zainicjowania obrony cywilnej. Obronę cywilną utożsamiano z ochroną ludności cywilnej podczas konfliktów zbrojnych. Pierwsze takie działania zaczęto podejmować tuż po zakończeniu pierwszej wojny światowej. Ich bezpośrednim powodem były ofiary spowodowane przeprowadzonymi po raz pierwszy w historii wojen bombardowaniami z powietrza. Państwami, które utworzyły organizacje będące zaczątkiem obrony cywilnej, były Francja, Anglia i Niemcy. Organizacja ta przyjęła nazwę System Obrony Przeciwlotniczej. W Polsce w 1921 r. powstało Polskie Towarzystwo Przeciwgazowe, z którego - po przekształceniach ustawą z 25 marca 1934 r. - powstała obrona przeciwlotnicza i przeciwgazowa.

Po drugiej wojnie światowej obrona cywilna przechodziła wiele przeobrażeń, a w 1967 r. ustawą z 21 listopada usankcjonowano funkcjonowanie w strukturach resortu obrony narodowej Obronę Cywilną Kraju. W zakresie jej zadań pojawił się nowy obszar - ochrona ludności w czasie klęsk żywiołowych i katastrof. Obrona cywilna pojawia się także w prawie międzynarodowym w kontekście ochrony osób cywilnych podczas konfliktów zbrojnych [9].

Rozwój stosunków międzynarodowych, zacieśnianie współpracy pomiędzy państwami, stworzenie wielu mechanizmów w postaci umów, konwencji o zasięgu międzynarodowym, a także powszechna globalizacja spowodowały, że zagrożenia z powodu konfliktów zbrojnych o charakterze międzynarodowym straciły na sile. Postęp technologiczny, osiągnięcia cywilizacji i oddziaływanie człowieka na klimat i środowisko generują zagrożenia dla zdrowia i życia ludzi, mienia oraz środowiska w postaci ekstremalnych zdarzeń klimatycznych, a także katastrof technicznych.

"Ochrona ludności" to pojęcie obejmujące szeroki zakres działań zapewniających bezpieczeństwo ludziom, mieniu i środowisku. Do kanonu funkcjonowania współczesnych państw wszedł obowiązek ochrony życia i zdrowia ludzi, mienia i dziedzictwa kulturowego oraz środowiska naturalnego w sytuacjach zagrożeń powstałych z przyczyn naturalnych lub spowodowanych przez człowieka jako zagrożeń współczesnej cywilizacji. Zaliczyć do nich można, oprócz zagrożeń naturalnych, także zagrożenia asymetryczne, terrorystyczne, cybernetyczne, hybrydowe oraz inne spowodowane przez człowieka - przede wszystkim zagrożenia militarne o gwałtownym i niszczycielskim wpływie na ludzi, infrastrukturę

\footnotetext{
5 Obecnie można stwierdzić, że inżynieria bezpieczeństwa cywilnego stanęła przed bardzo trudnym zadaniem ochrony ludzi i środowiska przed skutkami zaburzeń klimatycznych będących skutkiem nieodpowiedzialnej działalności człowieka.
} 
- first of all military threats causing violent and destructive impact on humans, the infrastructure and the natural environment [10]. At this point the fact should be emphasised that regulations of the European Union related to civil protection are both at the level of treaties and decisions of the European Parliament and the Council, and implementing decisions of the European Commission. The adopted Lisbon Treaty caused the incorporation of specific provisions dedicated to civil protection to the Treaty on European Union and the Treaty establishing the European Communities [11], [12].

So what is "civil protection" as described in definitions? For the purposes of this paper and problems discussed in it, the author makes use of the definition of civil protection contained in the bill on civil defence and civil protection.

"Civil protection is a complex of actions that are undertaken by relevant public authority bodies, rescue entities and the humanitarian component, as well as individual citizens. Those measures should minimise the consequences of events that endanger the life and health of the citizens, their property and the natural environment" [13]. This definition identifies two basic areas of operation of entities specified in the bill, the task of which is to ensure the required security level.

The areas of those measures are as follows:

- possibility of the occurrence of hazards, which comprise primarily. forecasting and monitoring hazards and assessing risk, counteracting the occurrence of hazards, preparing conditions for evacuation from endangered areas, preparing conditions for civil protection, securing the property and resources indispensable for the functioning of the population on a level that guarantees survival, assuring foodstuffs, medical care, pharmaceuticals etc.;

- occurrence of hazards and their identification, notification, warning and alerting, setting up hazardous zones, ensuring protection from the consequences of chemical, biological and radiological hazards as well as other measures.

The listed tasks of civil protection point to the interdisciplinary nature of activities of state bodies to ensure civil protection. It may be presumed that this scope is much more extensive than the scope of civil protection engineering.

Civil protection is based on the area of knowledge, skills and competencies of many scientific fields and scientific disciplines, such as technical, legal, organisational, economic, nature sciences, which in such a way establish a basis for a responsible and effective system of civil protection from the consequences of diverse hazards, which may be of natural origin, such as natural disasters, and also of civilisational origin, resulting from the industrialisation of life in the era of all-encompassing globalisation and technical disasters, including also hazards related to the state of war ${ }^{6}$.

The engineering methods adopted in the implementation of those tasks are based on the laws of many other scientific disciplines:

- "security science", where protection means assurance of security;

- "physics" in issues relating, i.a., to radiological hazards, ways of their identification, monitoring, etc.;

- "chemistry" - for example fire hazards, explosions, emissions of hazardous substances;

The bill on civil protection and civil defence stipulates that entities of civil protection in the state of war become transformed into entities of civil defence. i środowisko naturalne [10]. Warto wspomnieć, że regulacje Unii Europejskiej dotyczące ochrony ludności zawarte są zarówno na poziomie traktatów, jak i decyzji Parlamentu Europejskiego i Rady oraz decyzji wykonawczej Komisji Europejskiej. Przyjęty Traktat z Lizbony spowodował wprowadzenie do Traktatu o Unii Europejskiej i Traktatu ustanawiającego Wspólnotę Europejską konkretnych zapisów poświęconych ochronie ludności [11], [12].

Czym jest zatem „ochrona ludności”? Dla potrzeb niniejszego opracowania i omawianego w nim problemu autor posłuży się definicją ochrony ludności zawartą w projekcie ustawy o obronie cywilnej i ochronie ludności.

„Ochrona ludności to zespół działań podejmowanych przez właściwe organy władzy publicznej, podmioty ratownicze i komponent humanitarny, jak również pojedynczych obywateli. Działania te powinny zminimalizować skutki zdarzeń zagrażających życiu i zdrowiu obywateli, ich mieniu i środowisku naturalnemu" [13]. Przywołana definicja określa dwa podstawowe obszary działań podmiotów wskazanych w projekcie ustawy, których zadaniem jest zapewnienie właściwego poziomu bezpieczeństwa. Są to:

- możliwość wystąpienia zagrożenia - prognozowanie i monitorowanie zagrożeń i szacowanie ryzyk, przeciwdziałanie występowaniu zagrożeń, przygotowanie warunków ewakuacji z obszarów zagrożonych, przygotowanie warunków do ochrony ludności, zabezpieczenia mienia i środków niezbędnych do funkcjonowania ludności na poziomie gwarantującym przeżycie, zabezpieczenie środków żywnościowych, opieki medycznej, środków farmaceutycznych itp.;

- wystąpienie zagrożeń i ich rozpoznanie - powiadamianie, ostrzeganie i alarmowanie, wyznaczenie stref niebezpiecznych, zapewnienie ochrony przed skutkami zagrożeń chemicznych, biologicznych i radiologicznych i wielu innych.

Powyższe pokazuje interdyscyplinarność działań organów państwa na rzecz ochrony ludności. Można powiedzieć, że zakres ten jest o wiele szerszy od zakresu inżynierii bezpieczeństwa cywilnego.

Ochrona ludności opiera się o stan wiedzy, umiejętności i kompetencji wielu dziedzin nauk i dyscyplin naukowych, takich jak nauki techniczne, prawne, organizacyjne, ekonomiczne, przyrodnicze. W ten sposób tworzy podstawy do odpowiedzialnego i efektywnego systemu ochrony ludności przed skutkami różnego rodzaju zagrożeń pochodzenia naturalnego i cywilizacyjnego ${ }^{6}$.

Stosowane $w$ realizacji tych działań metody inżynierskie opierają się na prawach wielu innych dyscyplin naukowych:

- naukach o bezpieczeństwie, gdzie ochrona oznacza zapewnienie bezpieczeństwa;

- fizyce dot. np. zagrożeń radiologicznych, sposobów ich identyfikacji, monitorowania itp.;

- chemii dot. np. zagrożeń pożarowych, wybuchów, emisji substancji niebezpiecznych;

- matematyce dla określania prawdopodobieństwa wystąpienia danego zagrożenia, oceny i określenia wielkości ryzyka, określenia zasad ewakuacji;

- meteorologii dot. kwestii zagrożeń ekstremalnymi zjawiskami pogodowymi;

Projekt ustawy o ochronie ludności i obronie cywilnej stanowi, że podmioty ochrony ludności w stanie wojny przekształcają się w podmioty obrony cywilnej. 
- "mathematics" - for needs of defining the likelihood of occurrence of a given specific hazard, assessment and determination of risk magnitude, setting out evacuation rules etc..;

- "meteorology" - issues related to hazards arising from extreme weather conditions;

- "biology" such issues as e.g. epidemiological hazards for people, animals or plants;

- "management" - principles for the functioning of public administration responsible for crisis management, including for civil protection as the main task;

- "law", "economics" for example for purposes of evaluating the effectiveness of applied protection means, to determine the magnitude of damage and many other examples.

As indicated in the explanatory memorandum to the bill on civil protection and civil defence [13], the level of civil protection in situations of various types of hazards depends on the measures undertaken at diverse levels of public and economic administration, in such areas as public administration, power engineering, communication, science, national defence, education and upbringing, industrial economy, water management, environment, internal affairs, health and many others.

Knowledge gained from the abovementioned disciplines and fields affords a relatively comprehensive insight into the man-technology-environment system, and as a result it enables also the adoption of appropriate means of civil protection and the environment, adequate to the specific hazards of this system. This justifies the presumption that effective civil protection as a certain defined system of organisational undertakings and means, methods and technical tools, combines social knowledge in the scope of the discipline of security sciences, and technical know-how, and, to put it more precisely, knowledge in the scope of safety engineering, including also civil protection engineering.

Consequently, civil protection makes use of the methods, ways and means provided by technical knowledge. For this reason an equality sign may be placed between civil protection and civil protection engineering defined as preventing adverse consequences caused both by natural phenomena, and by human activity, and the elimination of such consequences with restoration of the environment affected by such consequences to the state from before the event.

Can therefore the concept of "civil protection engineering" be used with reference to the title of this article? The author is convinced that this is the case. This is due to the interdisciplinary nature of the security sciences, including civil protection sciences, as well as technical sciences, forming a clear and transparent system of civil protection, as a specific type of a system of civil safety to protect the civilians from adverse consequences of hazards coming from the natural environment and the technical environment (environment of production, obtaining and distribution of goods indispensable for human existence in the surrounding environment).

\section{Summary}

The conducted analysis of concepts and definitions that characterise the sphere of safety made it possible to find justification for the presumption implying that the modern civil protection system
- biologii dot. np. zagrożeń epidemicznych dla ludzi, zwierząt czy roślin;

- zarządzaniu odnośnie zasady funkcjonowania administracji publicznej, która jest odpowiedzialna za zarządzanie kryzysowe, w tym za ochronę ludności jako zadanie podstawowe;

- prawie i ekonomii np. do oceny efektywności stosowanych zabezpieczeń, określanie wielkości szkód i wiele innych przykładów.

Jak wynika z uzasadnienia, do projektu ustawy o ochronie ludności i obronie cywilnej [13] poziom ochrony ludności w obliczu zagrożeń zależy od działań podejmowanych na różnych szczeblach administracji publicznej i gospodarczej, w takich obszarach jak: finanse, łączność, nauka, obrona narodowa, oświata i wychowanie, gospodarka przemysłowa, gospodarka wodna, środowisko, sprawy wewnętrzne, zdrowie i wiele innych.

Wiedza zaczerpnięta z wymienionych dyscyplin i dziedzin pozwala na w miarę wszechstronne poznanie systemu człowiek-technika-środowisko, a przez to na przyjęcie odpowiednich, adekwatnych do zaistniałych zagrożeń tego systemu, środków ochrony ludności i środowiska. Można zatem skontestować, że efektywna ochrona ludności, jako pewien określony system przedsięwzięć organizacyjnych oraz środków, metod i narzędzi technicznych, łączy w sobie wiedzę społeczną z zakresu dyscypliny nauki o bezpieczeństwie oraz wiedzę techniczną, a mówiąc ściślej - wiedzę z zakresu inżynierii bezpieczeństwa, w tym inżynierii bezpieczeństwa cywilnego.

Ochrona ludności korzysta zatem z metod, sposobów i środków wiedzy technicznej. W związku z tym można postawić znak równości pomiędzy ochroną ludności a inżynierią bezpieczeństwa cywilnego definiowaną jako zapobieganie negatywnym skutkom wywoływanym zarówno przez zjawiska naturalne, jak i działalność człowieka i usuwanie tych skutków z przywracaniem dotkniętego tymi skutkami środowiska do stanu sprzed zdarzenia.

Czy zatem można - w nawiązaniu do tytułu artykułu - używać określenia „inżynieria ochrony ludności"? Autor jest przekonany, że tak. Wynika to bowiem z interdyscyplinarności nauk o bezpieczeństwie, w tym o ochronie ludności, a także nauk technicznych. Tworzą one jasny, przejrzysty system ochrony ludności jako swoisty rodzaj zabezpieczenia ludności przed negatywnymi skutkami zagrożeń ze strony środowiska naturalnego i środowiska technicznego (środowiska wytwarzania, pozyskiwania i dystrybucji dóbr niezbędnych do egzystencji człowieka w otaczającym go środowisku).

\section{Podsumowanie}

Przeprowadzona analiza pojęć i definicji charakteryzujących obszar bezpieczeństwa pozwoliła na uzasadnienie tezy, że współczesny system ochrony ludności powinien być oparty na inżynierii 
should be based on civil protection engineering. It is civil protection engineering, as specialist knowledge distinguished from the general area of safety engineering, that may serve as a basis for the organisation and functioning of an effective civil protection system, which would be capable of taking up efficient measures aimed at protecting people, their life, health, property, civilisational and cultural achievements and the environment from adverse consequences of hazards that may arise from the natural and civilisational environment. The basis of civil protection engineering is knowledge gained from diverse scientific spheres and disciplines and other similar compendiums of knowledge and practices, and for this reason the concept of "civil protection engineering" may be used to denote a wider conceptual field of "civil security engineering".

The concept of civil protection comprises a range of technical, nature and organisational sciences, forming the basis for the establishment of an effective system capable of efficiently counteracting hazards which present a threat to human health and life as well as property and the environment, which may arise from all types of catastrophic events with origins both in the surrounding natural environment and in the technical environment. Also, the tools at the disposal of technical and nature sciences allow the effective organisational development of the system and the rules for its functioning.

\section{Literature / Literatura}

[1] Maslow A., Motywacja a osobowość, PWN, Warszawa 2006.

[2] Radkowski S., Podstawy bezpiecznej techniki, Oficyna Wydawnicza Politechniki Warszawskiej, Warszawa 2003.

[3] Majer P., W poszukiwaniu uniwersalnej definicji bezpieczeństwa wewnętrznego, „Przegląd Bezpieczeństwa Wewnętrznego" 2012, 7(4), 11-18.

[4] Starzyński P., Nawacki M., Prawo karne materialne $w$ bezpieczeństwie, Difin, Warszawa 2013.

[5] Rozporządzenie Ministra Nauki i Szkolnictwa Wyższego z 12 lipca 2007 r. w sprawie standardów kształcenia dla poszczególnych kierunków oraz poziomów kształcenia, a także trybu tworzenia i warunków jakie musi spełnić uczelnia by prowadzić studia międzykierunkowe i makrokierunki (Dz.U. 2007 Nr 164, poz. 1166).

[6] Lutostański M., Dylematy polskiej klasyfikacji nauk w zakresie bezpieczeństwa: inżynieria bezpieczeństwa, „Zeszyty Naukowe AON" 2016, nr 3 (104).

[7] Pihowicz W., Inżynieria bezpieczeństwa technicznego. Problematyka podstawowa, WNT, Warszawa 2008. ochrony ludności. To właśnie inżynieria ochrony ludności jako wyodrębniona z ogólnego obszaru inżynierii bezpieczeństwa specjalistyczna wiedza może być podstawą do organizacji i funkcjonowania efektywnego systemu ochrony ludności. Systemu, który będzie w stanie podjąć skuteczne działania zabezpieczające ludzi, ich życie, zdrowie, mienie, dorobek cywilizacyjny i kulturowy przed negatywnymi skutkami zagrożeń ze strony środowiska naturalnego i cywilizacyjnego. Podstawą inżynierii ochrony ludności jest wiedza z różnych dziedzin i dyscyplin naukowych oraz innych zbiorów wiedzy i praktyk. Dlatego możemy używać określenia „inżynieria ochrony ludności” jako szerszego pojęciowo obszaru, jakim jest „inżynieria bezpieczeństwa cywilnego".

Ochrona ludności obejmuje swoim pojęciem zakres nauk technicznych, przyrodniczych, organizacyjnych, tworząc w ten sposób podstawy do zbudowania efektywnego systemu, który będzie $w$ stanie skutecznie przeciwstawić się zagrożeniom dla życia i zdrowia ludzi oraz mienia i środowiska ze strony różnego rodzaju zdarzeń katastroficznych mających swoje pochodzenie zarówno w otaczającym środowisku naturalnym, jak i środowisku technologicznym. Narzędzia, jakimi dysponują nauki techniczne i przyrodnicze, pozwalają natomiast na efektywne budowanie systemu i zasad jego funkcjonowania.

[8] Ustawa z 24 sierpnia 1991 r. o ochronie przeciwpożarowej (t.j. Dz.U. 2019 poz. 1372).

[9] Konwencja Genewska o ochronie osób cywilnych podczas wojny, Genewa, 12 sierpnia 1949 r. zał. nr 1. Protokół dodatkowy dot. ochrony ofiar międzynarodowych konfliktów zbrojnych sporządzony w Genewie 8 czerwca 1977.

[10] Wytyczne dotyczące definicji potencjalnego poważnego zagrożenia dla zdrowia ludzi lub zwierząt lub dla środowiska naturalnego w kontekście art. 33 ust. 1 i 2 dyrektywy 2001/82/WE (Dz.U.UE.C.06.132.32).

[11] Decyzja Rady UE z 23 października 2001 r. ustanawiająca mechanizm wspólnotowy ułatwiający wzmocnioną współpracę $w$ interwencjach wspierających ochronę ludności (2001/792/WE, Euratom).

[12] Decyzja Rady UE z 5 marca 2007 r. ustanawiająca Instrument Finansowy Ochrony Ludności (2007/162/WE).

[13] https://www.ock.gov.pl/prawo/projekty_aktow_prawnych, Uzasadnienie projektu ustawy o ochronie ludności i obronie cywilnej.

TADEUSZ TERLIKOWSKI, PH.D. ENG. - doctor of law, fire engineer, academic teacher, long-term vice-president for research and teaching affairs at the Main School of Fire Service and vice-president for organizational and didactic affairs at the Academy of Finance in Warsaw. Supervisor of several dozen diploma theses. Assistant professor at the Institute of Internal Security at the Main School of Fire Service (currently). He leads didactic classes and research in the field of legal issues related to safety.
DR INŻ. TADEUSZ TERLIKOWSKI - doktor prawa, inżynier pożarnictwa, nauczyciel akademicki, wieloletni prorektor ds. naukowo-dydaktycznych w Szkole Głównej Służby Pożarniczej oraz prorektor ds. organizacyjno-dydaktycznych w Akademii Finansów w Warszawie. Promotor kilkudziesięciu prac dyplomowych. Adiunkt w Instytucie Bezpieczeństwa Wewnętrznego Szkoły Głównej Służby Pożarniczej (obecnie). Prowadzi zajęcia dydaktyczne i badania w obszarze zagadnień prawnych $w$ bezpieczeństwie. 